\title{
The Function of Traditional Snacks and Fruits at Chinatown Semarang - A Case Study on Semarang Northcoast Maritime Culture
}

\author{
Catur Kepirianto ${ }^{1}$ \\ ${ }^{1}$ Department of Linguistics, Faculty of Humanities, Universitas Diponegoro, Semarang - Indonesia
}

\begin{abstract}
Traditional snacks and fruits are the culinary culture of Chinese community to fulfill Chinese daily consumption and ritual activities in Chinatown Semarang. It is a particular characteristic of social and local culture. As local wisdom, it provides a local value of the food products. This study aims to reveal varieties and functions of traditional snacks and fruits in Gang Baru traditional market Semarang. This research refers to theory and method of naming system and function. It is in a descriptive qualitative manner and describes names and functions of traditional snacks and fruits for ritual functions. The red and golden colors of snacks and fruits symbolize the source of fortune and wealth. Traditional snacks and fruits for the Chinese community function as ritual media to give offerings to ancestors rather than for daily consumption. The meaning and function of traditional snacks and fruits symbolize the fortune, luck, wealth, harmony, love, sharp mind, happiness, long life, calm and steady hearted, sincerity, blessing, and salvation. Hopefully, there would be a social impact to challenge the Industrial Revolution 4.0. It seems to refresh social paradigm and to recognize the high value of local wisdom, local skill, social skill, local ingredients, and local product.
\end{abstract}

Keywords: functions; traditional snacks and fruits; fortune; wealthy; happiness; SemarangChinatown.

\section{Introduction}

Language as a means of communication is a reflection of the culture of the community. The way the speakers of a language perceives the reality of the world. It can be understood from the language used in their daily lives. Through language, we can understand the speech culture. There is a good relationship between language and culture. Human uses language as a means of communication. Language has function to represent and reflect the human culture. Human shapes language and culture. Language is a sign system that is used as a symbol to represent human thoughts, concepts, and experiences [1]

Language and its symbols are used by humans to obtain knowledge. Language is a means of expression for humans. Language has the most complicated symbol [2]. This is reflected in the use of vocabularies used by humans. There are names and labels to express human culture and daily routine.

Unfortunately, some communities do not recognize the richness of their own language, symbols, and expressions. They sometimes face their daily lives from others and do not recognize their own culture. Though actually, it is their own local wisdom that is valuable for challenging the disruptive technology era, the Industrial Revolution 4.0.
There are traditional foods representing the culture of Semarang northcoast community. Varieties of foods are traditionally produced and cultivated locally. They are traditional snacks and fruits with their names, labels, and functions. This paper aims to reveal the functions of traditional snacks and fruits that are traded in Chinatown area, specifically in Gang Baru traditional market Semarang. Moreover, it would be the reminding for the social community in relation to the conscious of the rich of their own language and culture to face the disruptive era.

This ethnolinguistic research hopefully will be useful in the development of social environment and northcoast maritime culture. It is also useful to enrich the existence of ecotourism, local culture, local product, and local wisdom.

The research on the topic of traditional foods, especially the function of traditional snacks and fruits is very interesting. It is useful to preserve the existence of traditional snacks and fruits rather than modern ones. On any occasion, some social communities still remind the traditional culinary and food culture, easily find traditional snacks and fruits, and search back-tonature based culinary. Furthermore, this research would be useful to recognize the high value of local manners such as local wisdom, local ingredients, local product, 
and local skill. They are the basic needs for society to compete and survive in a global and disruptive era.

\section{Literary Review}

There are some literary reviews in this paper. In a meal ritual ceremony, people enjoy the food that has been given a prayer before being distributed. The meal ceremony which includes the custom of giving away sacred food will provide security, welfare, prosperity for the host and the family [3]. The religious communal prayer and communal meal ceremony was attended by relatives to achieve the health and smoothness of a series of events or a situation without any harm. There is a wish that what one desires will be realized [4]. Otherwise, they make a sacrifice, an offering. They offer foods, serve dish, put fruits and drinks on the table on which the meal was served up and offered. The consumption of foods can determine and reestablish the relationship between people and God, and between people [5].

Meal ceremony symbolizes the mystical and social unity of the participating participants in it: brothers, relatives, neighbors, fellow workers, relatives, local spirits, dead ancestors, and God. Cultural and religious rituals often function and associate the human life span with the life cycle. Life cycle is a stage passed by a living. Circulation of this period concerns important events, such as birth, marriage, until the death of someone [6].

\section{Research Methods}

It is descriptive qualitative research. This research applies simak libat cakap [7] and observer's paradox of William Labov [8] in which the researcher acquires speech acts from the respondents who act on traditional snacks and fruits at Gang Baru traditional market in Chinatown Semarang. The next step is data processing by classifying and analyzing the data in relation to the naming and the function of traditional snacks and fruits. Finally, the data are presented in a descriptive qualitative manner.

\section{Results and Discussion}

\subsection{Gang Baru Chinatown Traditional Market and Various Good Quality Commodities}

Gang Baru market in Chinatown Semarang is the only one traditional market sited in the Chinatown area of Semarang (San Bao Long Tang Ren Jie). Gang Baru traditional market is in a long path of 5-6 meters wide and 500 meters long. The pathname is Gang Baru which is also an area where Chinese people live since the midst of 18AD [9]. As a traditional market in Chinatown surroundings, pasar Gang Baru provides the needs of the ethnic groups, Chinese and Javanese who live in the Chinatown area and its surroundings.
Traders sell and trade the commodities on simple stalls from wood, bamboo, plastic, aluminum, zinc or iron pipes completed with a 2-meter paper umbrella on a paved road along Gang Baru path. Buying and selling take place from dawn around 5 early mornings to midday around 12 noon. Buying and selling take place through bargaining. Stalls are lined up on the left, right, and sometimes right in the middle of the path. The path is so narrow 5-6 meter wide and it is often called pasar senggol, the narrow market in a long path in which the shoppers bump into each other. The road between the stalls is so narrow that it always happens to be senggalsenggol, shaking or contacting the body or the intersection of luggage between shoppers.

Various qualified commodities are traded in Gang Baru traditional market from raw materials to ready-toeat cooked food.

The commodities or items sold in Gang Baru traditional market Chinatown Semarang are:

- Vegetables

- Fruits

- Snacks

- Meat and fish

- Spices

- Ritual equipment

- Fortune teller

- Dry goods and household items

- Clothes.

Those various items in Gang Baru traditional market Semarang Chinatown are various vegetables, cooking ingredients, many fruits, snacks, meat and fish, eggs, kitchen spices, grocery items, clothing, cleaning tools and household necessities, bread and cake ingredients, various plastics, ritual equipments, a place for fortune teller and consultations; cooked and ready-to-eat food, such as a number of dishes, pecel semanggi-cooked herb-with- trifoliate-leaf vegetable salad with peanut dressing, bubur-porridge, getuksnack made from yams or cassava, cakes and traditional snacks, wedang-hot cooked or boiled water for making hot drinks, wedang tahu- hot tofu drink.

In the context of global communication, traditional snacks have an increasingly important role to introduce the traditional culinary of Semarang and as a unique, specific, and interesting snack produced and become the trademark of Semarang. Traditional snacks also serve as a medium to introduce and develop tourism promotions. It can attract foreign tourists to visit and enjoy the traditional culinary of Semarang. Traditional snacks are also expected to have a function to increase community participation and also increase the economic level of the community.

Local and traditional foods are very important and phenomenal as the media to maintain and introduce the culture and traditions of Semarang community.

The commodities sold in Gang Baru traditional market Semarang are popular with high and good quality. It is reasonable since some commodities, especially traditional snacks and fruits are used by Chinese to be ritual items for altarpiece. The traditional 
snacks and fruits are the media to pray and to contact God and the holy spirit. The Chinese believe that they have to give the best offerings in praying. The better the offerings, the better livelihood, luck, and fortune they will have. It is the reason why the items and commodities sold in Gang Baru traditional market Semarang are guarantee on the lookout for high and good quality.

Table 1. Traditional snacks and fruits in Gang Baru traditional market Semarang

\begin{tabular}{|l|l|}
\hline \multicolumn{1}{|c|}{ Traditional Snacks } & \multicolumn{1}{c|}{ Fruits } \\
\hline kue ku (siu ku) & banana \\
\hline wajik tumpeng & pisang mas \\
\hline moho cake (hwat kue), & jeruk orange (chi tze) \\
\hline agar-agar, gelatin & srikaya, pomegranate \\
\hline manisan kolang kaling & belimbing starfruit \\
\hline manisan beligo (tung-kwa) & jeruk bali grapefruit \\
\hline ang-co date palm & \\
\hline kit-pia & \\
\hline long noodles (siu mie) & \\
\hline kue ku merah & \\
\hline
\end{tabular}

Based on the previous description, it is hoped that there would be a social impact to refresh the social paradigm and to recognize the high value of local wisdom, local skill, social skill, local ingredients, and local product. It seems to challenge the Industrial Revolution 4.0.

\subsection{Chinese Tradition}

There are 3 pillars on Chinese cultures and traditions. They are respect for ancestors, family culture or kinship system, and eating culture.

\subsubsection{Respect for Ancestors and Family Culture or Kinship System}

Every time there are ceremonies, traditional celebrations, holidays, and festivals, Chinese people try to be present and be at the home on the oldest relatives. The family members meet, gather, and chat while enjoying a variety of food and drinks. The meeting in the house of the oldest has a function as a medium for getting a good relationship between relatives and family, as well as a medium of respect for ancestors and a medium of respect for older relatives. The customs and culture of the Chinese community are respecting their ancestors and respecting older siblings. Chinese customs and culture are still held firmly by the Chinese community in Semarang. The expression that is often conveyed by Chinese people to others is "respect for older siblings or relatives and love younger siblings or relatives."

\subsubsection{Eating Culture (She Er)}

Every time there are ceremonies, traditional celebrations, holidays, and festivals, the Chinese people try to present and be at the home of the oldest relatives. In that place, the family members meet, gather, and chat while enjoying a variety of food and drinks. The meeting in the house of elders is as a medium for tightening the relationship between relatives and family. It is also a medium of respect for ancestors and a medium of respect for older relatives. The custom of the Chinese community is to respect those who are older and love those who are younger.

Eating for the Chinese community is a symbol of respect. In eating behavior, sharing a meal with relatives, colleagues, and friends is so common [10]. Eating is served not only to relatives who are still alive but also presented to ancestors and spirits who have died as offerings and homage to ancestors. The European community expresses their happiness by saying 'Say it with flower', while the Chinese people express their happiness by saying 'Say it with food'. The expression of Chinese talk when meeting someone is 'Have you eaten?'. Thus it can be understood that the importance of eating for the Chinese community.

Eating is a symbol of a gift or gift that is presented on a feast day or a holiday and not another gift or reward. Provision of food, for example, is delivered at Chinese New Year (Sin Cia) celebrations. It is the celebration of Imlek, the new year for the Chinese community. Chinese New Year celebrations are kue keranjang (nian gao) and kue mangkok merah, as well as lontong cap go meh which is held on the 15th day of the Chinese New Year or at the first full moon in the Chinese New Year. On ancestral prayer days, Ceng Beng, it is provided with 3 animals. At the time of Peh Cun, the activity was eating bak cang (sticky rice combined with chopped pork meat wrapped in bamboo leaves, shaped into a diamond and steamed), while on Tiong Jiu celebrations it is celebrated by eating kue bulan, moon cakes (Tiong Jiu Pia). The culture of eating for Chinese society has been going on for thousands of years.

The Chinese proverb is "Food is the foremost", Min Yi Shi Wei Tian. Food has a primary and very important meaning. Even the Chinese have the courage and determination to suffer so they can eat. According to the history of the Chinese, the peasants and ordinary people experienced suffering for thousands of years. This makes the Chinese community behave prioritizing eating problems or stomach consumption problems. Chinese farmers always try and work hard to produce food and vegetables. Chinese teachings that are hereditary are 'one grain of rice has a high value and meaning ', so it should not be wasted because 'there is no one grain of rice comes easily'. Throwing or wasting food is the same as doing karma or sin.

Eating together is one of the pillars of Chinese culture and has become a tradition that lives in Chinese society. Relatives gather to celebrate togetherness. Before eating together, the food they faced was first offered to the ancestors as a form of devotion and ethics to their predecessors. 


\subsection{The Names of Traditional Snacks}

Traditional snacks in Gang Baru traditional market, Semarang Chinatown are classified into three groups. They are cake traditional snacks, ready-to-eat food traditional snacks, and fruit traditional snacks. Cake traditional snacks and food traditional snacks can be bought from traders selling various snacks or various traditional snacks. Cake traditional snacks are usually packed in each one, neatly arranged, lengthwise, and placed in plastic trays. Each tray contains one type of cake traditional snack.

Ready-to-eat food traditional snacks are placed in a variety of packages. Ready-to-eat food traditional snacks that can be packaged each unit are usually sold on a plastic tray on a wide stall table. Whereas food traditional snacks such as bubur, porridge that cannot be packaged in one pack will be placed in pots. Each pot contains one type of bubur, porridge.

\subsection{The Function of Traditional Snacks at Gang Baru Chinatown Market, Semarang}

Traditional snacks are in the form of food cakes that have ritual function related to certain colors. Mostly they are red and golden colors. Red has meaning and function as a source of fortune. While the golden color has a meaning as a symbol of wealth because gold is a precious metal that has a high value and price. Traditional snacks for the Chinese community function as ritual media as offerings to ancestors and also function for daily consumption needs. The meaning and function of traditional snacks as a symbol. It means the source of fortune, luck, wealthy, efforts to live in harmony, love each other, sharp mind, happiness, long life, calm and steady hearted, sincerity, blessing, and salvation.

Various foods that are used for praying are various traditional snacks or cakes and fruits, such as kue $k u$ (siu ku), wajik tumpeng, moho cake (hwat kue), gelatin, manisan kolang kaling, manisan beligo (tung-kwa), ang-co, kit-pia, long noodles (siu mie), and kue ku merah, banana, pisang mas, orange, srikaya, pomegranate, starfruit, grapefruit,

\section{Kuе $k u(\operatorname{siu} k u)$}

Kue ku (siu ku) symbolizes long life. Anyone consumes $k u e k u$ or siu $k u$ that has function to lengthen their life. They can stay and live together with the next generation.

\section{Wajik Tumpeng}

Wajik tumpeng, a diamond-shaped pastry made of glutinous rice grains, coconut milk, and sugar is a symbol of noble knowledge, so that they are disseminated according to the form of their pointed shapes at the end of the upper part and expand and widen at the bottom, so that the bottom is wider and wider. Another meaning is that the leadership or leader is chosen from people who have extensive faith and knowledge and are virtuous, comprehending, understanding something good and right can distinguish between right and wrong. Something good and right should be disseminated, while something bad and wrong is not disseminated and even needs guidance to achieve good and right attitudes and actions.

\section{Kue moho (hwat kue)}

Kue moho (hwat kue) symbolizes the source of fortune so that someone can do and give charity from his fortune. Moho cakes are round and overflow or bloom into 4 parts which are symbols of the source of fortune from 4 directions of compass. The expected meaning is fortune sourced from all directions and abundant. With abundant fortune, a prosperous, peaceful and happy life will be achieved.

\section{Agar-agar, gelatin}

Gelatin has a specific meaning so that this life becomes bright. Hearts and human feelings in a light-hearted state so that someone will easily reach their expectations and ideals.

\section{Manisan kolang-kaling}

Manisan kolang-kaling, candies made of sugar palm fruit symbolizes steady heartedness, determination and determination so that one can work steadily in daily activities. Manisan kolang-kaling also symbolizes that humans should always remember and do not forget the gift and fortune of God. Any human reminds and remember various things so that her life becomes healthy, happy, calm, and successful.

\section{Manisan beligo (tung- $k w a)$}

Manisan beligo, candies made of wax gourd (tung$k w a$ ) gives the meaning that the activities of human life should run sincerely so that every work he does feels easy and does not feel heavy. With an attitude of sincerity, every job will be carried out lightly and well. There is no burden that hinders every activity so that all activities and work will take place smoothly and successfully.

Ang-Co, date palm

Ang-co, is considered as a food source for the Gods. Ang-co symbolizes blessing so that God's blessings are expected to make it easier for humans to do various kinds of activities and works. With blessing, humans will get easier and relief in various aspects of life.

Kit-pia

Kit-pia has the function and meaning of safety, security. With the kit-pia offerings, it is expected that humans will get young and mind. With the physical and spiritual conditions that are safe, humans will be healthier, happier and more prosperous. All will always be in a state of being both physically and spiritually, survived in the world and in the hereafter.

\section{Mie Panjang (Siu mie)}

Mie panjang, long noodles or siu mie has the function and meaning as the name suggests, namely long. With long noodle offerings (siu mie), humans are expected 
to have a long life and can take advantage of longevity to obtain everything for the happiness and welfare of the family and relatives. Siu mie also symbolizes cheap fortune. Humans with cheap fortune will be able to achieve all desires and hopes.

Kue $k u$ merah a red cupcake made of rice flour, wheat flour, fermented cassava, and sugar (ang ku kue)

Kue ku merah (ang ku kue) is a symbol of longevity. Kue ku merah consists of a symbol of turtles which generally has a long-lived meaning. Presenting it by serving kue ku merah offerings is expected that someone will have a long life that is beneficial for themselves to get money.

\section{Banana}

Banana is a symbol of harmony in the family and also harmony in the living to foster unity among community members.

\section{Pisang mas, a very small, sweet finger-sized banana} Pisang mas is a symbol of living in harmony and loving one another. Living in harmony is very important so that each member can work together to achieve common goals. By living in harmony, fortune even though a little will develop into a lot of fortune and become rich. By eating pisang mas, someone will love each other. Pisang mas is a symbol of mutual love for others.

\section{Jeruk (chi tze)}

Citrus fruit symbolizes the fortune. Citrus fruits contain the meaning of luck because the word chi means lucky. With orange fruit offerings, it is hoped that luck will always come for family welfare and prosperity.

\section{Buah srikaya}

Srikaya symbolizes rich. The rich or wealth are expected to achieve and obtain.

\section{Buah Delima (pomegranate)}

Pomegranate is a symbol of harmony in a family. By living in harmony, members of a society will be successful and happy. Therefore, offerings in worship include pomegranates with hope in a life that is harmonious, peaceful, and happy.

\section{Belimbing (starfruit)}

Starfruit symbolizes the sharping mind. It is a hope to be smart. By sharping the mind, someone will do their activities easily and can succeed successfully.

\section{Jeruk bali (grapefruit)}

Jeruk bali is a symbol of happy. With happiness someone will be healthy, peaceful, and prosperous. Happiness is the ideal of everyone in navigating life. The purpose of human life is basically to achieve happiness.

\section{Conclusion}

Traditional snacks and fruits are commodities that can be found and obtained through buying and selling at the Chinatown Gang Baru traditional market Semarang.

Traditional foods consist of snacks and fruits that are used to meet daily needs and for ritual needs of the Chinese community. It would develop the environment culture that recognizes the local product, social skill, and local wisdom.

Traditional snacks have various functions such as sources of good, luck, wealth, living in harmony, love each other, sharp minds, happiness, long life, calm and a calm heart, sincerity, blessings, welfare, and prosperity.

This research would be useful to recognize the high value of local manners such as local wisdom, local ingredients, local product, and local skill. They are the basic needs for society to compete and survive in a global and disruptive era to challenge the Industrial Revolution 4.0 .

\section{References}

1. L.M. Ahearn, Living Language: An Introduction to Linguistic Anthropology (2012)

2. S.I. Hayakawa, Simbol-Simbol (2009)

3. Koentjaraningrat, Kebudayaan Jawa, SEI.2 (1994)

4. N. Mulder, Mistisisme Jawa. Ideologi di Indonesia (2009)

5. G. Ma, Food, Eating Behavior, and Culture in Chinese Society, EF 2, 195-199 (2015)

6. H. Geertz, Keluarga Jawa (1983)

7. Sudaryanto Metode dan Aneka Teknik Analisis Bahasa (1993)

8. R. Wardhaugh, An Introduction to Sociolinguistics (1988)

9. R.R. Soenarto, T.B. Tionghoa. Budaya Tionghoa Pecinan Semarang Zhong Hoa Wen Hu (2013)

10. S. Higgs, J. Thomas, Social Influences on Eating, BS. 9, 1-6 (2016) 